\title{
Accelerated aging studies of the selected commercial films
}

\author{
Magdalena Cichecka ${ }^{1), *)}$ (ORCID ID: 0000-0003-4675-4695), Beata Pałys ${ }^{1)}$ (0000-0002-9460-3528), \\ Bożena Wilbik-Hałgas ${ }^{1)}$ (0000-0002-9409-4014), Marcin H. Struszczyk ${ }^{1)}{ }_{(0000-0002-1788-7862)}$
}

DOI: dx.doi.org/10.14314/polimery.2021.6.3

\begin{abstract}
The Arrhenius method was used to investigate the effect of accelerated aging conditions on the physical and mechanical properties of polymer films for technical, medical, food and office applications. Temperature and UV radiation were taken into account as environmental factors. It was shown that the tested films are more sensitive to thermal degradation than UV radiation. The reduction in tensile strength after thermal aging does not exceed $40 \%$, and in the case of UV radiation, $14 \%$. The estimated lifetime of the tested films is over 5 years.
\end{abstract}

Keywords: films, mechanical properties, accelerated aging, Arrhenius method.

\section{Badania przyspieszonego starzenia wybranych folii handlowych}

Streszczenie: Metodą Arrheniusa zbadano wpływ warunków przyspieszonego starzenia na właściwości fizyko-mechaniczne folii polimerowych do zastosowań technicznych, medycznych, spożywczych i biurowych. Jako czynniki środowiskowe uwzględniono temperaturę i promieniowanie UV. Wykazano, że badane folie są bardziej wrażliwe na degradację termiczną niż promieniowanie UV. Zmniejszenie wytrzymałości na rozciąganie po starzeniu termicznym nie przekracza $40 \%$, a w przypadku promieniowania UV, 14\%. Oszacowany czas życia badanych folii wynosi ponad 5 lat.

Słowa kluczowe: folie, właściwości mechaniczne, przyspieszone starzenie, metoda Arrheniusa.

Plastics production has increased more than 20-fold during the past half-century. In 2015 alone, global plastics production was about 322 million tons, and reached 335 tons in 2016 [1, 2]. Due to the low cost, transparency, durability and easy processing, polymers have been widely used in agriculture, industry, and human life. The disadvantages of plastics are low resistance to high temperature and poorer mechanical properties, compared to, e.g. metals or ceramics.

Films are made of polymers or non-ferrous metals up to $2 \mathrm{~mm}$ thickness. Plastic films are most often made by the following methods:

- blow moulding extrusion (molten polymer is extruded through the slot in a circular cross-section, and air pressure makes it form a sleeve),

- cast extrusion (molten polymer is extruded through a flat nozzle and cast on a cooled mould).

Films may be single or multi-layer. In the second case, the film consists of different layers of materials, thanks to which it combines the features of components. Films may also be combined with paper or aluminum. Polymers used for films are most often polyethylene (PE), polypropylene (PP), ethylene copolymers with vinyl acetate or vinyl alcohol, ethylene copolymers with methacrylic

1) Institute of Security Technologies „MORATEX”, ul. Marii Skłodowskiej-Curie 3, 90-505 Łódź, Poland.

*) Author for correspondence: itb@moratex.eu acid, polyvinyl alcohol and fluoropolymers. Properties that determine the durability of films are characterized by numerous indicators, physical values. Amongst the required properties are:

- technological (linear dimensions, composition, mass per unit area, manufacturing defects, colour, printed design, gloss),

- physical (composition, mass per unit area, density, change of dimensions - shrinkage, flatness deviation, flexibility),

- tensile [strength and elongation, tear resistance, resistance to puncture (free-falling dart method), adhesion, surface coefficient of friction, weld strength, resistance to separation of layers],

- bio-physical, ecological and hygienic (water absorption, migration of dyes, transmission of odour and flavour, penetration of water steam, water permeability, oxygen penetration, fat penetration, monomer content),

- special (susceptibility to formation, thermal resistance, wettability, electrostatic properties),

- barrier (resistance to microorganisms, UV radiation, high temperature),

- sensorial,

- aesthetic.

Films are used as materials with a long durability period. Depending on the type, the period of storage in appropriate conditions (temperature below $25^{\circ} \mathrm{C}$, no access of moisture, light, oxygen, ozone, and chemical 
substances, position preventing deformations) is 3-25 years. However, the precise forecasting of the durability period under conditions of use, the so-called lifetime is very important for safety reasons. Changes can result from both chemical (chemical degradation) and physical factors (physical degradation). The service life is defined as the service life after which the material reaches the threshold level of the test value (usually $50 \%$ of the initial value) at the service temperature. For the Arrhenius method, this value is determined by extrapolating a linear relationship to the service temperature. In literature, the other terms can also be found [3, 4]:

- storage life, shelf life, i.e. the maximum period from the date of cross-linking to the date of installation (the first use of the product),

- service life, i.e. the expected lifetime or the acceptable period of use (manufacturer's warranty).

The storage life depends on conditions in which the product is stored.

Over time, the physical properties of the film can change in-different ways and, as a result, become useless due to excessive hardening, softening, breaking or other surface damage. Changes in physical properties may be caused by environmental factors, such as oxygen, ozone, light, and increased temperature.

Artificial accelerated aging tests, which usually expose materials to artificial light sources and simulated environment conditions, are commonly conducted to evaluate the weatherability and service life of polymeric materials $[5,6]$.

Changes in physical properties also depend on the chemical composition of the film $[7,8]$.

The aim of the study was to determine the influence of factors related to the accelerated aging process, taking into account temperature or UV radiation as environmental factors, on the maintenance of the physical and mechanical properties of films. Additional effects included the selection and determination of the physical properties of films and aging conditions in the context of determining the temperature, exposure time, UV radiation dose, as well as the final determination of the impact of the accelerated aging simulation process on the change of selected physical and mechanical properties of the films before and after pre-set time intervals.

\section{EXPERIMENTAL PART}

\section{Materials}

The plastic films for various purposes were tested, i.e.:

- technical film on anti-flooding sleeves (two types): sample 1 - anti-flooding sleeve Z 2 and sample 2 - antiflooding sleeve W 2

- film for packaging of medical products (three types): sample 3 - double-layer film, sample 4 - double-layer film and sample 5 - triple-layer film

- food film (one type): sample 6
- office film intended for punched pockets (one type): sample 7.

The basic physical properties of the tested films (sample 1-7) are presented in Table 1.

\section{Methods}

Mass per unit area, thickness and density were determined according to PBM-53/ITB procedure "Plastic Foils research methods". The test of mass per unit area consisted in determining the mass of the samples with a specific area $\left(100 \mathrm{~cm}^{2}\right)$, and then expressing them in $\mathrm{g} / \mathrm{m}^{2}$ with accuracy to three significant figures. The thickness of the samples was measured with an accuracy of $0,01 \mathrm{~mm}$ at a specific measuring pressure $0,5-1,0 \mathrm{~N}$ and a measuring foot with a specific diameter $2,5-10,0 \mathrm{~mm}$. The density was calculated using the mass per unit area of the samples and their thickness according to the formula $\mathrm{Q}=\mathrm{m} / \mathrm{V}$, where $\mathrm{m}$ is the mass of the sample and $\mathrm{V}$ - its volume.

Tensile strength was measured with an Instron universal testing machine according to PN-EN ISO 527-3:2019-01 standard.

Exposure to environmental factors such as temperature and UV radiation were determined according to ASTM F1980-16, PN-EN ISO 291:2010 standardand PBM-53/ITB:2019 procedure.

The tests were carried out on conditioned samples after the accelerated aging, taking into account the following time intervals: 3 years and 5 years.

The aging simulation included an incubation at temperature and the effects of ultraviolet radiation. Plastic films acc. to the requirements of point 5.3 of the PN-C89273:1997 standard should be stored at room temperature $18-22^{\circ} \mathrm{C}$ and relative humidity $50-70 \%$.

\section{Accelerated aging with temperature factor}

The accelerated aging process was carried out in accordance with ASTM F1980-16 standard, using temperature as the aging factor $[9,10]$.

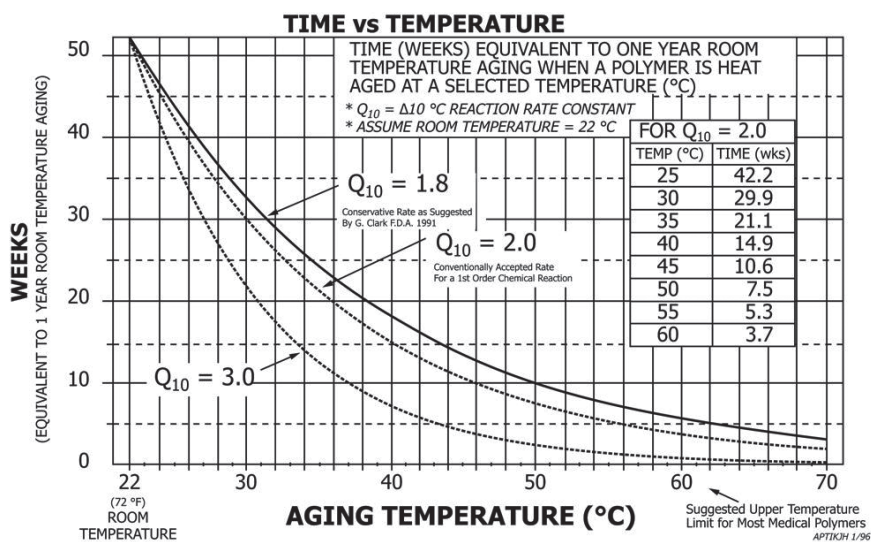

Fig. 1. Accelerated aging of polymer 
The time to carry out the accelerated aging process was determined on the basis of the coefficient characteristics of the Arrhenius method as shown in Fig. 1.

The Binder KMF 240 climatic chamber (Binder $\mathrm{GmbH}$, Germany) was used, enabling the achievement of the temperature $(20-80) \pm 2^{\circ} \mathrm{C}$ and relative humidity $<20 \pm 5 \%$. The storage life of the films was determined using the Arrhenius equation.

The following test conditions were established: temperature $65 \pm 2{ }^{\circ} \mathrm{C}$ and relative humidity below $20 \%$.

The Arrhenius equation was used to determine the time intervals in the aging process:

$\mathrm{AAF}=2.0^{(65-22) / 10} ; \mathrm{AAF}=2.0^{4,3}=19.7$

$\mathrm{AAT}=365 / 19.70=18.5$

where:

AAT - accelerated aging time, duration of accelerated aging

AAF - accelerated aging factor, the estimated or calculated ratio of the time to achieve the same level of change in physical properties as the sterile barrier system stored under real time (RT) conditions. An accelerated aging factor (AAF) estimate is calculated using the following equation: $\mathrm{AAF}=\mathrm{Q}_{10}{ }^{\text {[(TAA-TRT)/10], }}$

where:

$\mathrm{T}_{\mathrm{AA}}$ - accelerated aging temperature, ${ }^{\circ} \mathrm{C}$

$\mathrm{T}_{\mathrm{RT}}$ - ambient temperature ${ }^{\circ} \mathrm{C}$
It was assumed that one year of ageing would be achieved by incubating the sample for 18.5 days, two years for 37 days, 3 years -55.5 days, 5 years -92.5 days with air flow $\leq 1 \mathrm{ml} / \mathrm{s}$ and atmospheric pressure of 860-1060 hPa.

\section{Accelerated aging with UV factor}

The accelerated aging process was conducted on the basis of the guidelines specified in the following standards: PN-EN ISO 4892-1:2016-06, PN-EN ISO 4892-2:2013-06 and PN-EN ISO 105-B02:2014-11.

Time interval was 3 and 5 years.With the pre-set intensity of $600 \mathrm{~W} / \mathrm{m}^{2}$ within the range of wavelength 300 $800 \mathrm{~nm}$, the equivalent of natural radiation energy within month in the climatic zone of Central Europe in the UV aging chamber is achieved within 79 hours (the average annual sum of radiation dose for Poland is $3600 \mathrm{MJ} / \mathrm{m}^{2}$ ) [13-15]. Aging under an influence of UV radiation was carried out in a chamber for aging tests with a xenon arc lamp in an air-cooled xenotest Alpha (Atlas Material Testing Technology $\mathrm{GmbH}$, Germany), which allows the following conditions to be achieved: wavelength $\lambda=300-400 \mathrm{~nm}$, radiation intensity $160 \mathrm{~W} / \mathrm{m}^{2}$, temperature $38-40^{\circ} \mathrm{C}$ (black thermometer temperature $75^{\circ} \mathrm{C}$ ) and humidity $40 \%$, testing time was $200 \mathrm{~h}$, during which the radiation dose was $109899 \mathrm{~kJ} / \mathrm{m}^{2}$ [15].

T a b l e 1. Physical parameters of the tested films

\begin{tabular}{|c|c|c|c|c|}
\hline Film & $\begin{array}{l}\text { Mass per unit area } \\
\mathrm{g} / \mathrm{m}^{2}\end{array}$ & $\begin{array}{c}\text { Thickness } \\
\text { mm }\end{array}$ & $\begin{array}{l}\text { Density } \\
\mathrm{g} / \mathrm{cm}^{3}\end{array}$ & $\begin{array}{c}\text { Composition acc. to } \\
\text { the manufacturer's } \\
\text { declaration }\end{array}$ \\
\hline $\begin{array}{l}\text { Sample } 1 \\
\text { Sample } 1^{*} \\
\text { Sample } 1^{* *}\end{array}$ & $\begin{array}{l}166 \pm 2 \\
164 \pm 3 \\
156 \pm 4\end{array}$ & $\begin{array}{l}0.19 \pm 0.02 \\
0.17 \pm 0.02 \\
0.16 \pm 0.02\end{array}$ & $\begin{array}{l}0.87 \pm 0.03 \\
0.96 \pm 0.02 \\
0.97 \pm 0.02\end{array}$ & PET \\
\hline $\begin{array}{l}\text { Sample } 2 \\
\text { Sample } 2^{*} \\
\text { Sample } 2^{* *}\end{array}$ & $\begin{array}{l}173 \pm 6 \\
186 \pm 6 \\
168 \pm 1\end{array}$ & $\begin{array}{l}0.17 \pm 0.02 \\
0.19 \pm 0.02 \\
0.17 \pm 0.02\end{array}$ & $\begin{array}{l}1.04 \pm 0.03 \\
1.00 \pm 0.05 \\
0.99 \pm 0.01\end{array}$ & PET \\
\hline $\begin{array}{l}\text { Sample } 3 \\
\text { Sample } 3^{*} \\
\text { Sample } 3^{* *} \\
\text { Sample } 3^{* * *}\end{array}$ & $\begin{array}{l}100 \pm 1 \\
107 \pm 3 \\
106 \pm 1 \\
101 \pm 2\end{array}$ & $\begin{array}{l}0.10 \pm 0.02 \\
0.11 \pm 0.02 \\
0.11 \pm 0.02 \\
0.10 \pm 0.02\end{array}$ & $\begin{array}{l}0.98 \pm 0.03 \\
1.00 \pm 0.05 \\
0.97 \pm 0.01 \\
1.00 \pm 0.02\end{array}$ & $\mathrm{PP} / \mathrm{PA}$ \\
\hline $\begin{array}{l}\text { Sample } 4 \\
\text { Sample } 4^{*} \\
\text { Sample } 4^{* *} \\
\text { Sample } 4^{* * *}\end{array}$ & $\begin{array}{l}109 \pm 1 \\
117 \pm 1 \\
116 \pm 2 \\
111 \pm 2\end{array}$ & $\begin{array}{l}0.10 \pm 0.02 \\
0.10 \pm 0.02 \\
0.10 \pm 0.02 \\
0.10 \pm 0.02\end{array}$ & $\begin{array}{l}1.09 \pm 0.01 \\
1.17 \pm 0.01 \\
1.16 \pm 0.02 \\
1.10 \pm 0.02\end{array}$ & $\mathrm{PP} / \mathrm{PP}$ \\
\hline $\begin{array}{l}\text { Sample } 5 \\
\text { Sample } 5^{*} \\
\text { Sample } 5^{* *} \\
\text { Sample } 5^{* * *}\end{array}$ & $\begin{array}{l}102 \pm 1 \\
106 \pm 1 \\
108 \pm 2 \\
105 \pm 2\end{array}$ & $\begin{array}{l}0.08 \pm 0.02 \\
0.09 \pm 0.02 \\
0.09 \pm 0.02 \\
0.09 \pm 0.02\end{array}$ & $\begin{array}{l}1.27 \pm 0.01 \\
1.18 \pm 0.01 \\
1.20 \pm 0.03 \\
1.21 \pm 0.08\end{array}$ & PES/PE/PP \\
\hline $\begin{array}{l}\text { Sample } 6 \\
\text { Sample } 6^{*} \\
\text { Sample } 6^{* *}\end{array}$ & $\begin{array}{l}5.85 \pm 0.10 \\
5.89 \pm 0.50 \\
5.99 \pm 0.10\end{array}$ & $\begin{array}{l}0.013 \pm 0.001 \\
0.011 \pm 0.001 \\
0.012 \pm 0.001\end{array}$ & $\begin{array}{l}0.45 \pm 0.01 \\
0.53 \pm 0.02 \\
0.49 \pm 0.05\end{array}$ & PET \\
\hline $\begin{array}{l}\text { Sample } 7 \\
\text { Sample } 7^{*} \\
\text { Sample } 7^{* *}\end{array}$ & $\begin{array}{l}51.6 \pm 0.1 \\
54.6 \pm 0.1 \\
54.0 \pm 0.9\end{array}$ & $\begin{array}{l}0.059 \pm 0.003 \\
0.059 \pm 0.003 \\
0.066 \pm 0.021\end{array}$ & $\begin{array}{l}0.87 \pm 0.02 \\
0.93 \pm 0.01 \\
0.77 \pm 0.01\end{array}$ & PP \\
\hline
\end{tabular}

* sample after three years of thermal aging

**sample after five years of thermal aging

${ }^{* * *}$ sample after UV aging 


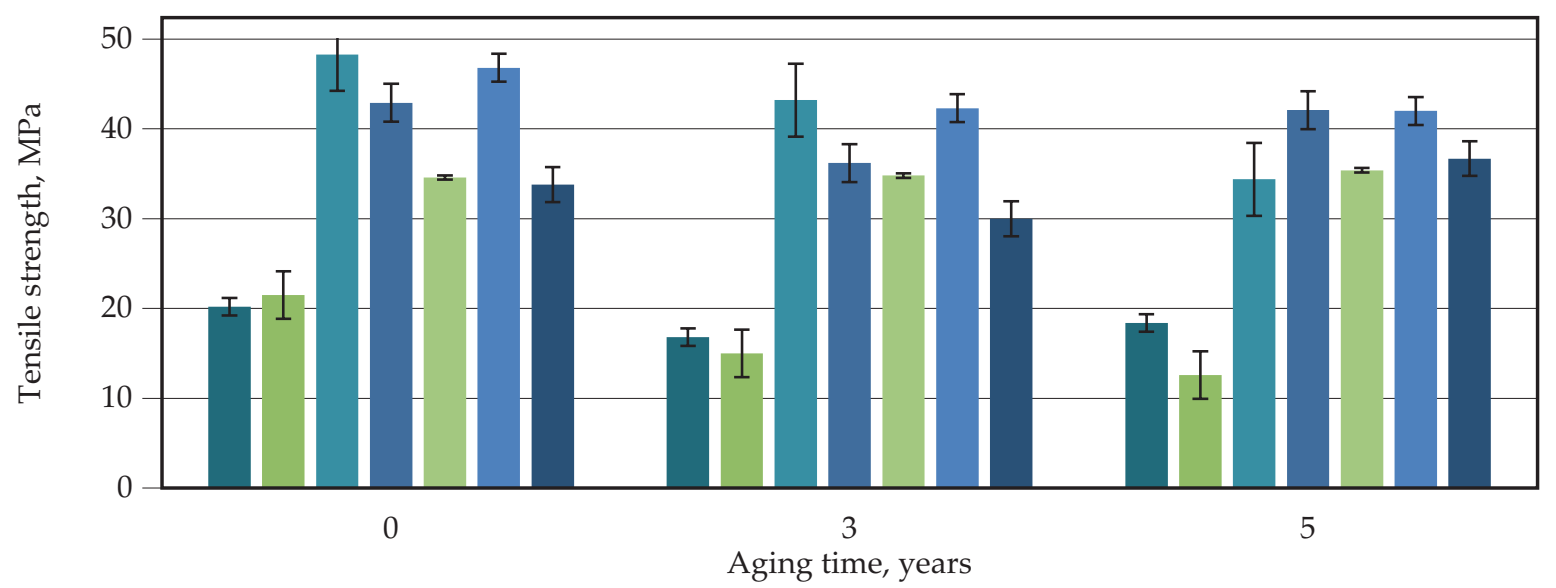

Sample $1 \square$ Sample $2 \square$ Sample $3 \square$ Sample $4 \square$ Sample $5 \square$ Sample $6 \square$ Sample 7

Fig. 2. Tensile strength in the longitudinal direction as a function of aging time at $65^{\circ} \mathrm{C}$

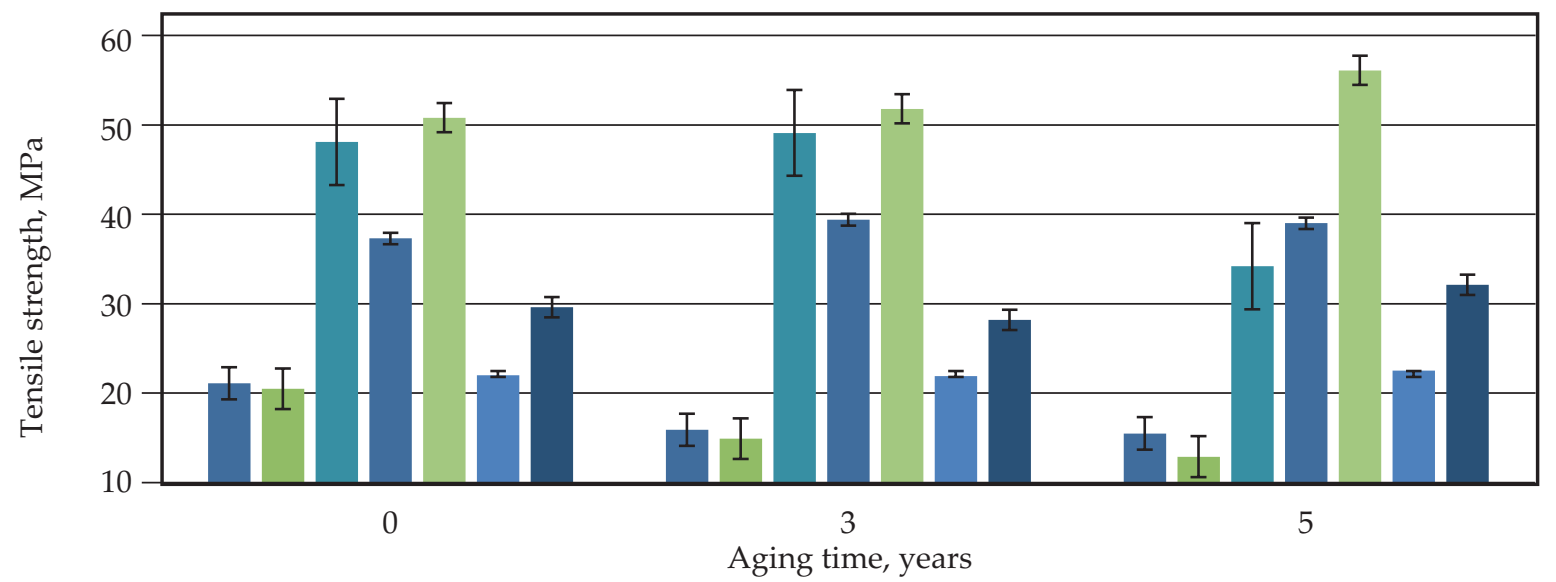

Sample 1 Sample $2 \backsim$ Sample $3 \square$ Sample $4 \square$ Sample $5 \square$ Sample $6 \square$ Sample 7

Fig. 3. Tensile strength in the crosswise direction as a function of aging time at $65^{\circ} \mathrm{C}$

\section{RESULTS AND DISCUSSION}

The physical and mechanical properties of films are assessed in a laboratory using appropriately selected research methods. With the reservation that the more the property determination method is closer to actual conditions of use, the closer the assessment to the conditions of actual use.

The laboratory conditions also allow the simulation of accelerated aging in the temperature and UV radiation terms, reflecting the lifetime of the material.

With regard to the selected mechanical parameters, the graphic interpretation of the obtained test results is presented in Figs. 2-7.
Changes in the value of tensile strength in the longitudinal direction after aging for 3 and 5 years range from 0.5 to $41.5 \%$ (Fig. 2). The best result was obtained for sample 5 (PES/PE/ PP). In this case, the tensile strength has practically not changed, which suggests the best resistance to thermal degradation. The greatest decrease in tensile strength was observed for sample 2 (PET), which proves the lowest resistance to thermal degradation.

The observed changes in the value of tensile strength in the crosswise direction after the aging periods of 3 and 5 years range from $0,5 \%$ to $37 \%$ (Fig. 3). Sample 6 (PET) showed the highest resistance to thermal aging and sample 2 (PET) the lowest. The differences in sensitivity to thermal aging of samples 6 and 2 (both PET films) indi- 


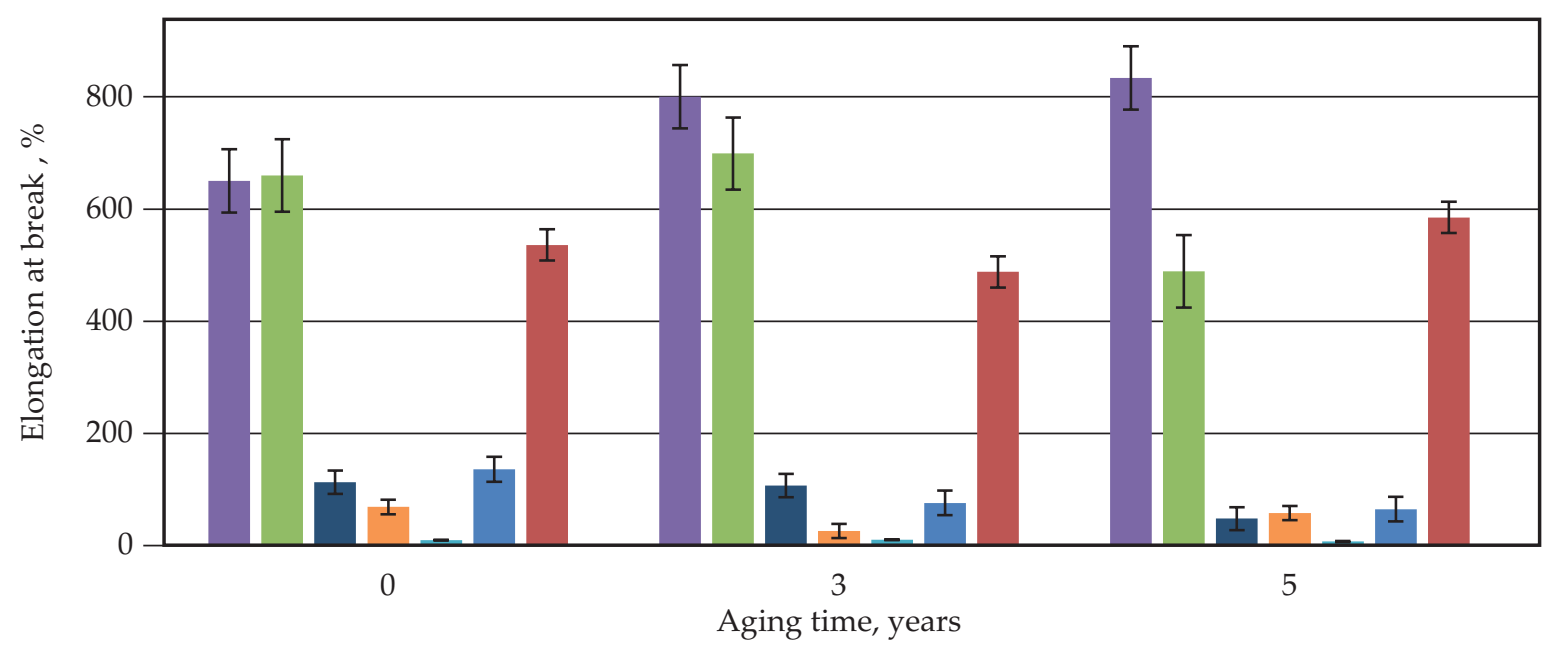

Sample 1 Sample $2 \square$ Sample $3 \backsim$ Sample 4 Sample $5 \square$ Sample $6 \square$ Sample 7

Fig. 4. Elongation at break in the longitudinal direction as a function of aging time at $65^{\circ} \mathrm{C}$

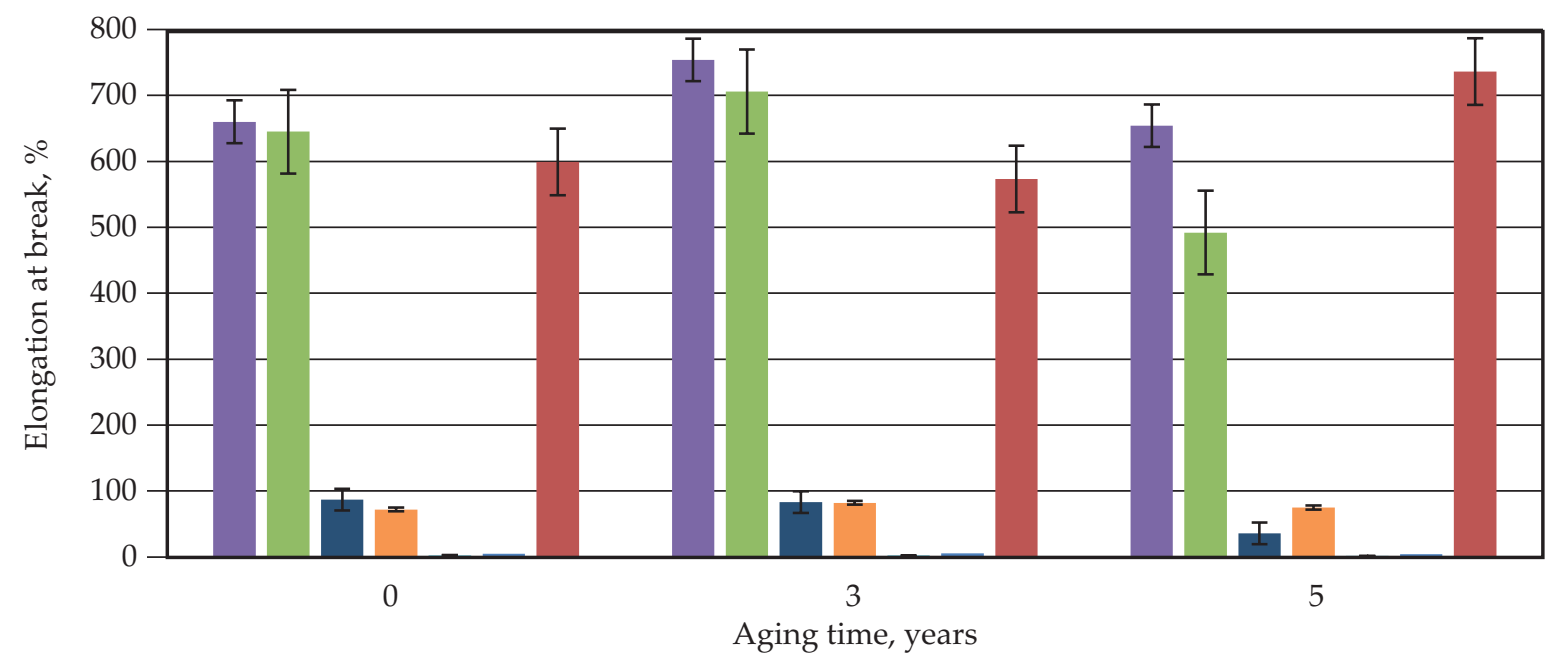

Sample $1 \square$ Sample $2 \square$ Sample $3 \backsim$ Sample $4 \square$ Sample $5 \square$ Sample $6 \square$ Sample 7

Fig. 5. Elongation at break in the crosswise direction as a function of aging time at $65^{\circ} \mathrm{C}$

cate a chemical modification of sample 6, which increased its resistance to aging.

As expected, the changes in elongation at break in both directions after the aging periods of 3 and 5 years are much greater than in the tensile strength, ranging from $1 \%$ to $63 \%$ (Figs. 4 and 5). Additionally, the sensitivity to thermal aging depends on the cutting direction of the samples (longitudinally or crosswise). In the longitudinal direction, sample 7 (PP) had the best thermal aging resistance, and sample 6 (PET) the worst. However, in the crosswise direction, the best resistance to thermal aging was recorded for sample 2 (PET), and the worst for sample 5 (PES/PE/PP).

It can be seen that the tested films are more sensitive to thermal degradation than UV radiation, as evidenced by changes in the tensile strength values after exposure to UV radiation, which do not exceed $14 \%$ (Fig. 6). The best resistance to $\mathrm{UV}$ was recorded for sample $4(\mathrm{PP} / \mathrm{PP})$, and the worst for sample 3 (PP/PA).

It can be seen from Fig. 7 that in the both directions, the value of elongation at break after exposure to UV radiation increased only in the case of sample 4 (PP/PP), and for the 


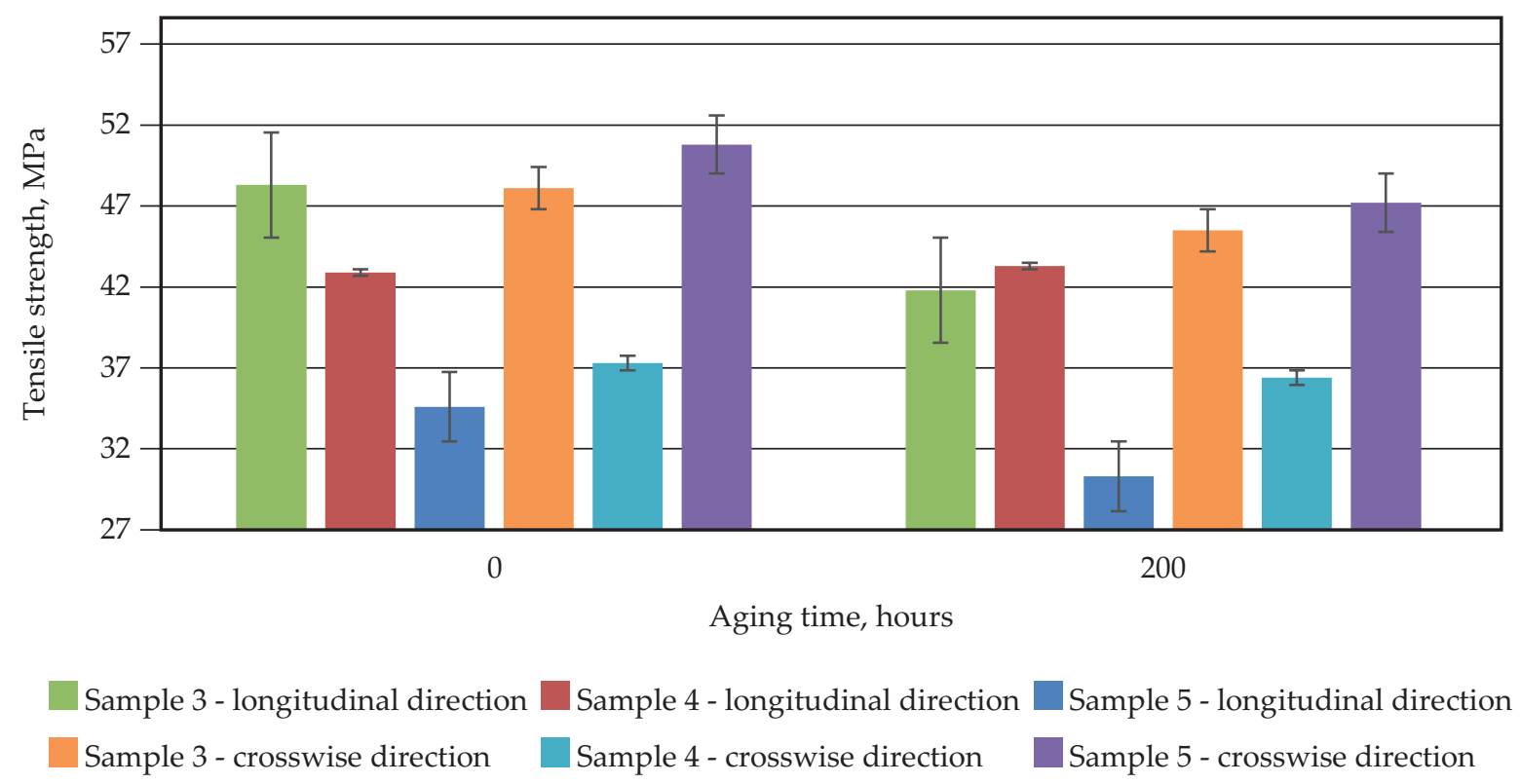

Fig. 6. Tensile strength in the longitudinal and crosswise direction as a function of aging time after UV radiation $\left(160 \mathrm{~W} / \mathrm{m}^{2}, 320 \mathrm{~nm}\right)$

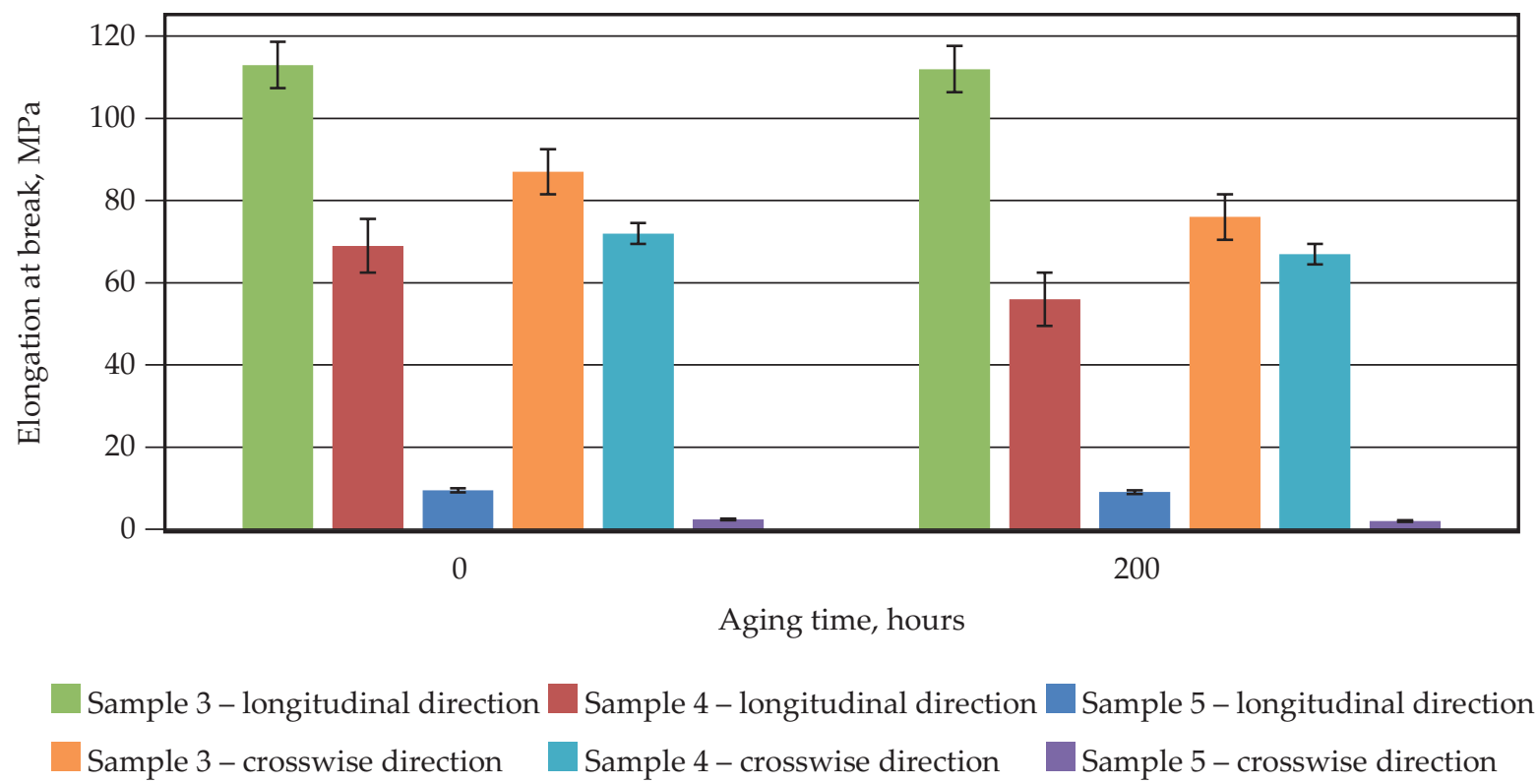

Fig. 7. Elongation at break in the longitudinal and crosswise direction as a function of simulated aging time after UV radiation (160 $\left.\mathrm{W} / \mathrm{m}^{2}, 320 \mathrm{~nm}\right)$

remaining samples it is reduced. This confirms the greater resistance of PP to UV than the other tested polymers.

\section{CONCLUSIONS}

Physical parameters (mass per unit area, thickness, density) after thermal and UV aging remain at the same level. Results do not differ between each other by more than $10 \%$. The tested films are more sensitive to thermal degradation than UV radiation, as evidenced by changes in the tensile strength after exposure to UV radiation, which do not exceed $14 \%$. The decrease in the value of tensile strength after the thermal aging does not exceed $40 \%$. The lifetime of all the tested samples exceeds 5 years, in the case of none of the tested films, a $50 \%$ of decline decrease in the level of the measured parameters in relation to the initial value was achieved.

\section{ACKNOWLEDGEMENTS}

The research was carried out within the framework of a research task that was part of statutory activity of the Institute of Security Technologies "MORATEX", supported by the Minister of Science and Higher Education. 


\section{REFERENCES}

[1] Jambeck J.R., Geyer R., Wilcox C. et al.: Science 2015, $347,768$.

https://doi.org/10.1126/science.1260352

[2] Rochman C.M., Browne M.A., Halpern B.S. et al.: Nature 2013, 494, 169.

https://doi.org/10.1038/494169a

[3] Lewandowski M., Pawłowska U.: Elastomery 2016, 20 (2), 24.

[4] Lewandowski M., Kleps T., Piaskiewicz M.: Przemyst Chemiczny 2012, 91 (8), 1591.

[5] Gillen K.T., Celina M., Clough R.L. et al.: Trends in Polymer Science 1997, 5 (8), 250.

[6] Qin J., Jiang J., Tao Y. et al.: Polymer Testing 2021, 93, 106940.

https://doi.org/10.1016/j.polymertesting.2020.106940

[7] Gillen K.T., Bernstein R., Celina M.: Rubber Chemistry and Technology 2015, 88 (1), 1.

https://doi.org/10.5254/rct.14.85930
[8] White J.R., Turnbull A.: Journal of Materials Science 1994, 29, 584.

https://doi.org/10.1007/BF00445969

[9] Overview of accelerated and real time aging's role in package validation, 03.2017. https://www.westpak.com

[10] ASTM vs ISTA for package testing - which is better, 06.2017. https://www.westpak.com

[11] Sample size rationale for medical device package validation, 12.2017. https://www.westpak.com

[12] Jachowicz T., Sikora R.: Polimery 2006, 51 (3), 177.

[13] Kamocka-Bronisz R., Blukacz M., Bronisz S.: Zeszyty Naukowe SGSP 2016, 58, 119.

[14] Łężak K., Bartkowiak G., Frydrych I.: Przeglad Włókienniczy - Włókno, Odzież, Skóra 2011, 3, 31.

[15] Book - Weathering Testing Guidebook - ATLAS http://www.strenometer.dk/files/downloads/guidebook.pdf

Received 14 IV 2021

\section{Rapid Communications}

Przypominamy Autorom, że publikujemy artykuły typu Rapid Communications - prace oryginalne wyłącznie w języku angielskim (o objętości 4-5 stron maszynopisu z podwójną interlinią, zawierające 2-3 rysunki lub 1-2 tabele), którym umożliwiamy szybką ścieżkę druku (do 3 miesięcy od chwili ich otrzymania przez Redakcję). Artykuł należy przygotować wg wymagań redakcyjnych zamieszczonych we wskazówkach dla P.T. Autorów.

We remind Authors that we publish articles of the Rapid Communications type - the original papers, in English only (with a volume of 4-5 pages of double-spaced typescript, containing 2-3 figures or 1-2 tables), which allow a fast print path (up to 3 months from when they are received by the Editorial Board). The article should be prepared according to the editorial requirements included in the Guide for Authors. 